\title{
VI МІЖНАРОДНА КОНФЕРЕНЦІЯ «ЦИФРОВА ОСВІТА В ПРИРОДНИЧИХ УНІВЕРСИТЕТАХ»
}

\author{
21-22 листопада 2019 р., м. Вроилав, Республіка Польща \\ https://doi.org/10.37472/2707-305X-2019-1-1-3-6
}

Вже шостий рік поспіль восени відбувається Міжнародна конференція «Цифрова освіта в природничих університетах». Цьогорічна зустріч фахівців цифрової трансформації університетської освіти пройшла у Вроцлавському університеті природничих наук. Організаторами заходу стали представники Центру дистанційної освіти Вроцлавського університету природничих наук. Співорганізаторами конференції від України виступили Інститут інформаційних технологій і засобів навчання Національної академії педагогічних наук України (далі - ІІТЗН НАПН України) і Національний університет біоресурсів та природокористування України.

Конференція мала на меті популяризувати знання про електронну освіту та освіту, що підтримується новими технологіями, серед викладачів і студентів університетів. Девіз конференції: «Е-матеріали - біль творчості та мистецтво використання». Тематика була розкрита в двох областях: технологічний аспект підготовки електронних навчальних матеріалів і гуманістичний вимір їх використання.

Участь трьох країн (Вірменія, Польща, Україна) сприяла інтеграції академічного суспільства навколо проголошеної тематики. Доповідачі секційних засідань та учасники панельних дискусій презентували різні підходи до розв'язання сучасних проблем суспільства, заснованого на знаннях, що переживає революційні зміни у формах і методах опановування цих знань.

Треба зазначити, що колеги, які представляли вищу освіту Польщі, більшою мірою зосереджували увагу присутніх на впровадженні авторських методик використання електронних матеріалів як додаткових інструментів очної форми здобуття освіти, а також на застосуванні прийомів заохочення та мотивації студентів до навчання. Серед іншого: освітній ефект від використання вебінарів та елементів гейміфікації; змішане навчання в

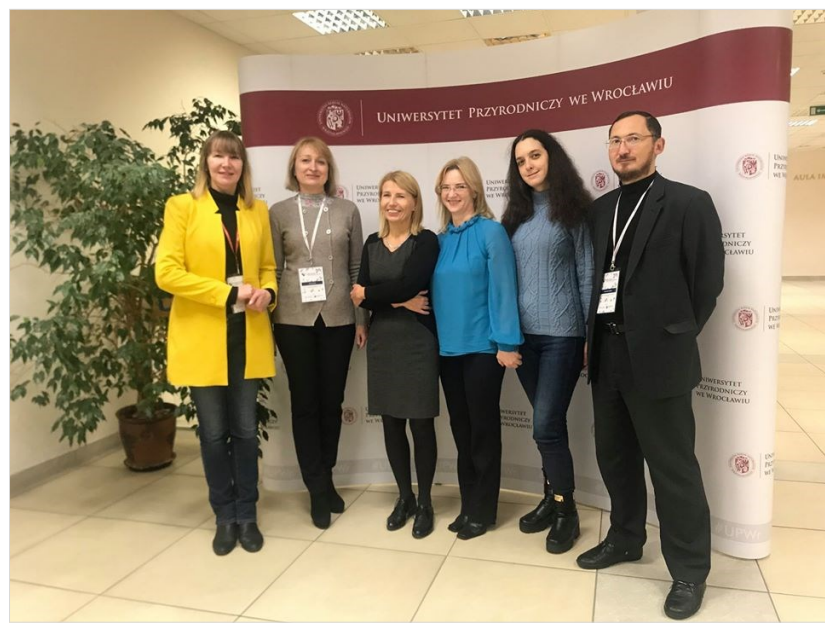

мовній освіті; масові відкриті онлайн курси для стислих термінів навчання тощо.

Команда викладачів з Вірменії презентувала власні розробки оцифрування навчальних матеріалів як діяльності, що орієнтована на учнів, та познайомила учасників конференції із організацією навчання на різних рівнях освіти Вірменії в IT-сфері.

Вітчизняний доробок у галузі освітніх застосувань інформаційно-комунікаційних технологій представили: заступник директора ІІТЗН НАПН України Ольга Пінчук, завідувач відділу технологій відкритого навчального середовища ІІТЗН НАПН України Світлана Литвинова, докторант ІІТЗН НАПН України Майя Марієнко, а також декан факультету інформаційних технологій Національного університету біоресурсів та природокористування України Олена Глазунова, завідувач кафедри інформатики і кібернетики Мелітопольського державного педагогічного університету імені Богдана Хмельницького В'ячеслав Осадчий і викладач Сумського національного аграрного університету Михайло Геєнко.

Українські науковці у представлених доповідях охопили широке коло проблем, привернули увагу колег до компетентнісних і технологічних питань. 
Так, наприклад, важливим технологічним аспектом підготовки навчальних матеріалів для синхронної навчальної взаємодії $€$ вибір програмного забезпечення, яке можна безкоштовно встановити на власні сервери (наприклад, Big Blue Button або OpenMeeting); користуватися у хмарі, також безкоштовно (наприклад, групові дзвінки Skype, Google+ Hangouts, Facebook Live або YouTube Live) або купувати для корпоративного використання (наприклад, Cisco Webex, Blackboard Collaborate або GoToWebinar та інші). Оскільки кожен із варіантів має як переваги, так і недоліки, то це питання викликало жваві дискусії серед присутніх.

Віртуальна і доповнена реальність - актуальні теми для освітніх форумів. Українські вчені запропонували розглядати це питання з позиції створення сучасного відеоконтенту, що впливає на еволюцію інструментів, форм і методів навчання не тільки у вищій, а у загальній середній освіті.

Відомо, що одним з найбільш ефективних методів формування інтегральної компетентності (професійні компетенції та м'які навички) $\epsilon$ проектна діяльність студента. Викладачами українських університетів було представлено апробований педагогічний прийом, коли студенти вимушені вирішувати складне завдання, сформульоване поза межами однієї дисципліни. Виконання завдання пропонується здійснювати 3 використанням електронного середовища, що забезпечить необхідний набір ресурсів і послуг для реалізації міждисциплінарних проектів, адаптованого для роботи в команді.

Також делегацією Інституту інформаційних технологій і засобів навчання НАПН України було представлено окремі аспекти досліджень, що обґрунтовують хмарне навчально-дослідне середовище закладу вищої освіти як середовище, у якому цілеспрямовано будується віртуалізована комп'ютерно-технологічна (корпоративна чи гібридна) інфраструктура для реалізації комп'ютерно-процедурної функції (наприклад, змістовно-технологічні та інформаційнокомунікаційні функції).

Як і в попередні роки, конференція супроводжувалася семінарами-тренінгами не тільки для викладачів, а й для студентів.

Темою для панельних обговорень стало питання: «Електронні ресурси для студентів - це відповідальність викладачів чи університетів?».

У переважній більшості університетів країнучасниць конференції студенти мають доступ до електронних джерел інформації. Так звані, «оцифровані знання» часто мають зручне мультимедійне представлення. Кожен із університетів розробив технології, що підтримують навчання, створив власну модель діяльності для організації доступу студентів до електронних матеріалів.

Учасниками конференції було рекомендовано використовувати різні моделі цифровізації освітньої діяльності. Найбільш актуальними виявилися наступні.

Модель 1. Викладачі, використовуючи платформу університету (або факультету), самостійно готують і роблять доступними для студентів власні / оригінальні чи відкриті електронні джерела знань, а також навчаються, як це зробити добре, проводять експерименти та вдосконалюють власні методичні методи і технічні компетенції тощо.

Модель 2. Викладачі отримують допомогу технічного чи методичного характеру від команди технічної підтримки для створення та використання електронних навчальних матеріалів. Наприклад, у формі навчання або індивідуальних консультацій, а також застосовуючи готові, заздалегідь визначені шаблони електронного курсу.

Модель 3. Університет інвестує в професійний колектив, відповідальний за підготовку електронних курсів на основі змістових матеріалів, наданих викладачами та у тісній співпраці з ними.

\section{ПІНЧУК Ольга Павлівна}

кандидат педагогічних наук, старший науковий співробітник, заступник директора з науковоекспериментальної роботи Інституту інформачійних технологій і засобів навчання Національної академії педагогічних наук України, м. Київ, Україна 


\section{6th INTERNATIONAL CONFERENCE "DIGITAL EDUCATION AT ENVIRONMENTAL UNIVERSITIES"} November 20-21, 2019, Wrocław, Poland

Olga Pinchuk

PhD in Pedagogy, Senior Researcher, Deputy Director for Scientific Experimental Work, Institute of Information

Technologies and Learning Tools of the National Academy of Educational Sciences of Ukraine, Kyiv, Ukraine

Abstract. In November 20-21, 2019 the 6th International Conference "Digital Education at Environmental Universities" was held. The Distance Educational Centre of the Wrocław University of Environmental and Life Sciences was the annual event organizer. Ukrainian co-organizers of the conference were the Institute of Information Technologies and Learning Tools of the National Academy of Educational Sciences of Ukraine and National University of Life and Environmental Sciences of Ukraine.

Keywords: international conference; digital education; environmental education; model of educational activity.

Дата публікації: 23 грудня 2019 р. 